\title{
Book Review on Far from the Madding Crowd by Thomas Hardy
}

\author{
Santanu Panda \\ Department of English (M.A student), SKB University, Purulia
}

\begin{abstract}
Hardys novels are generally known as the novel of co existence of characters and nature. Novelist likes Hardy in that Victorian England almost not imaginable apparently. Hardys first novel is The Poor Man and the Lady which is later destroyed. His first published novel is Desperate Remedies (1871). Under the Greenwood Tree (1872) is another novel both of which were published anonymously. His other novels include Far from the Madding Crowd (1874), The Return of the Native (1878), The Mayor of Caster bridge (1886), The Woodlanders (1887), and Tess of the d'Urbervilles (1891), Jude the Obscure,(1895) are prominent.
\end{abstract}

This novel Far from the madding crowd was first serialized in the "Cornhill Magazine" from January to December of 1874. In the novel Hardy first use the imaginary landscape of wesex. Hardy's Wesex is partly imaginary and party based on the geography on south west England. The novel contains 57 chapters.

The title of the novel is "Far from the madding crowd" is taken from the lines of Gray's Elegy written in a country churchyard "far from the madding crowd ignoble strife/ their sober never learned to stay". In this novel the title is presented ironically. The plot of the novel suggests not a sober and humble life far from the madding crowd. The plot unfolds lust, greed and murder which again reminds us of the madding crowd of urban class.

The Victorian society was speedily replacing the belief by science. The theory of Darwin about the mystery of creation shattered the concept of Genesis. As a result a more merciful Christian God is replaced by whimsical Fate. Hardy was much influenced by classical tragedies. The present novel forms a pattern of tragedy where chance and not reason develops the action.

Hardy sketches different kinds of characters. Some of the characters are major who leads the story and some are minor who are supporting the majors. One of the most important characters of the novel is Gabriel Oak. The novelist describes Oak with a comparison of oak tree. Hardy presents Oak as farmer thus suggesting his association with country life. His surname is Oak suggesting nature. When Gabriel smiles his eyes and diverging wrinkles resembles sketch of sun. The Oak is associated with nature. The character of Gabriel Oak follows a middle line. Hardy here refers to the allusion of Revelation in which John rebukes the laodiceans for being neither cold nor hot. Hardy also implies that the character Oak follows the survival theory of an Oak tree neither too high to be destroyed nor too low to be flooded. Like an oak tree Gabriel's character is also flexible. According to public opinion he doesn't follow a fixed character thus Oak is ready to change and moderate his identity according to crisis unlike the character of Boldwood and Troy. Oak's apparent appearance doesn't follow the common style. His hat is odd but it protects it from high wind. Hardy adds humor about his Coat. It is wide like of Dr Johnson. In Boswell's book Journal of a tour to the hedrides. Dr Johnson is described as wearing a very wide brown coat that can carry two volumes of his folio dictionary. Again Hardy comments that Oak's boot is so large that water cannot dampen his feet. All these exaggeration imply that like an oak tree Gabriel has two important features dimension and solidity. But Hardy also focuses on the mind of Oak. Beneath his simple and unworthy appearance there lies a strong mind. From a thoughtful view Oak is a man for whom mind is more responsible than body. More over his perceptible bend of solder is a flexible gesture of accepting anything calmly to conclude oak fulfills the philosophy of Hardy 'slighted and enduring'. Another important character of the novel is Bathsheba everdene who is the protagonist of the novel. Bathsheba is described as a fair product of nature. Bathsheba is compared with both 'kingfisher' and 'hawk'. Both of them are known for their rapidity and noiseless action. When Bathsheba lead herself flat on the horseback she had the rapidity 
and noiseless of such birds. Hardy comments that Bathsheba is a product of nature, she is as free as a bird. Bathsheba also reveals the tantalizing personality. She like a bird that wants to be free. Her mind is as free as bird. It is to be noted that Bathsheba's surname in Everdene. The word 'dene' echoes the sense of 'dean' a wooded valley. Bathsheba delivers a message to Gabriel Oak that she has no suitors that reveals her character. Another important character of the novel is William Boldwood. His name also signifies the blindness of a person. Boldwood is totally different from oak. He is rigid. He can't accept the situation. That is cause of his destruction. Fanny Robin is another important female character in the novel. Fanny is introduced in the novel as a 'Timid Girl'. A sweet romantic girl too weak to work. She is probably the most innocent and most suffered by Troy as well as the others. The Rustic characters like CainyBall, Jan Coggan, Mrs Hurst, Mrs Coggan plays important role throughout the novel.

The novelist presents a simple theme in a new way. He starts the novel with the description of Farmer Oak. He has a farm and leads a very simple life far from the madding crowd. But suddenly he saw Bathsheba though it doesn't disturb his regular life but he finds a deep feeling for her. Here Hardy parallels between the stalk exchange and exact calculation. In stalk exchange shares are exchanged on exact calculation but in respect of emotional exchange no calculation matters. Hardy here refers to the emotion of Gabriel. Gabriel feels a strong liking for Bathsheba and he secretly watches Bathsheba who gave him a note that she has no suitor as her aunt told him about it. Oak's all the sheep is died for the mislead of dog Geroge the son. And Bathsheba is inherited a farm of her uncle. Gabriel shows a remarkable energy and strength after it. His all lifelong saving was wiped out and now he is a pauper but he accepts it calmly and makes a simple reply 'thank God I'm not married'. Oak took the job in Bathsheba's farm. He doesn't hesitate to take the appointment as a shepherd in his beloved farm. Another farmer Boldwood suddenly came there Bathsheba sent her a valentine card containing the message 'Merry Me' without the sender's name. Hardy here presents the 'folly' of Bathsheba. Boldwood first time saw her in the market but he didn't notice her but the word 'Merry Me' starts his identity. Another character 'Troy' firstly deserted Fanny Robin. The misinterpretation of 'All Saint' and 'All Souls' plays the cruel part in Fanny's life. Just like James Harthouse in dickens Hard Times Troy too only belongs and is responsible to the present whims and changing fortune are his marks. He brings misfortune not in Bathsheba and Fanny's life but also Boldwood's life. Troy's military brightness with his shord is first instance of his possession of Bathsheba. Actually he creates a protective boundary around Bathsheba. Boldwood's looses all his control after the news of Bathsheba's marriage with Troy. Suddenly a storm appears both Gabriel Oak and Bathsheba mutually help to protect the harvest but Troy ignored it and enjoys a party. Fanny Robin who is carrying the child of Troy is humiliated by all. But here Hardy presents the greatness of nature. She is supported by a street dog to carry her body. Troy begins to neglect Bathsheba. She understands that she has given herself very cheaply. He states that 'a ceremony before priest doesn't make a marriage'. Actually he flirts with Fanny and married to Bathsheba. He called Fanny 'you are my very very wife'. After Fanny's death the romanticism of Troy is significant. He brought an expensive tomb stone and decorated her grave with flower. The rain water destroyed the decoration and made staned on the tomb. Actually Fanny took his revenge on Troy. Suddenly Troy disappears and there is a chance for Boldwood to reunion with Bathsheba. But after six years when Boldwood is going to propose Bathsheba on his tea party Troy came back and Boldwood loses his sanity and shoot Troy. After Troy's death and Boldwood's sentenced Oak request Bathsheba not to renew his contract because he is leaving the place. But at last Bathsheba and Gabriel got married and the novel ends happily.

The novelist builds the plot with different situation. The novelist introduces character with the description and significance of their name. All their name suggesting some important characteristic. The suspense of marriage and relationship between the characters are very important. The climax scene comes when Boldwood gives a tea party in honor of Bathsheba. Troy suddenly came and Boldwood shoot him. The novel ends with the conventional happy ending of the reunion of hero and heroine i.e. Oak and Bathsheba.

The writing style of Hardy is prominent. He uses emotion as well as intellect. Hardy uses symbol to justify the character. He compares Bathsheba with 'hawk' and 'kingfisher' for her noiseless action and Oak with 'oak tree' for dimension and solidity. Troy is compared with 'city of troy' for his snobbery and manners. He uses the symbol of 'Napoleon at St. Helena' for describing George son the dog who leads the lamb to death. He also uses the allusion from Exodus, Paradise Lost, Juno and Jupitar etc 
This very novel Far from the Madding crowd is thematically links with Hardys other contemporary novel. A novel named Jude the Obscure of Hardy points out some similarity of plot and themes with Far from the Madding crowd. The periodicals written in that contemporary time also elaborates such kind of extraordinary themes and characters in a Fiction or Drama. The rustics play a role in Far from the Madding crowd but in Tess of the D'urbervilles and Jude the Obscure there is no role of rustics.

H.G.Moore quotes that 'This particular novel is a cult in the history of British English Literature'. Thomas Hardy successfully sketches the Victorian society in his novel.

\section{AUTHOR's BIOGRAPHY}

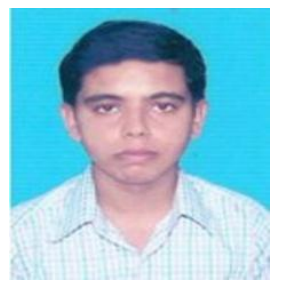

Santanu Panda, is a Master Degree student of Sidho-Kanho-Birsha University, Purulia, West Bengal, India. His areas of interest include Indian English Literature, Gothic Literature and British Literature. He has presented papers on National and International seminars and Published in International Journals.

Citation: Suzanne B., Flack-Yi. "Book Review On Far From the Madding Crowd By Thomas Hardy." International Journal on Studies in English Language and Literature (IJSELL), vol 5, no. 8, 2017, pp. 1-3. doi: http://dx.doi.org/10.20431/2347-3134.0508001.

Copyright: (C) 2017 Authors. This is an open-access article distributed under the terms of the Creative Commons Attribution License, which permits unrestricted use, distribution, and reproduction in any medium, provided the original author and source are credited. 